\title{
The Applying of GIS in Identification of Structural-Functional Units at Urban Areas (Mysłowice Town Case Study, Silesian Upland)
}

\author{
Tomasz Parusel $^{\mathrm{a}}$, Anna Kowalczyk ${ }^{\mathrm{b}}$, Jarosław Banaszek ${ }^{\mathrm{a}}$, Weronika Dragan ${ }^{\mathrm{c}}$ \\ ${ }^{a}$ Department of Physical Geography, Faculty of Earth Sciences, University of Silesia, 60 Będzińska Street, PL-41-200 Sosnowiec, Poland \\ ${ }^{b}$ Department of Cadastre and Spatial Management, Faculty of Geodesy and Land Management, University of Warmia and Mazury, \\ 15 Prawocheńskiego Street, PL-10-724 Olsztyn, Poland \\ ${ }^{c}$ Department of Economy Geography, Faculty of Earth Sciences, University of Silesia, 60 Będzińska Street, PL-41-200 Sosnowiec, Poland
}

\begin{abstract}
The Mysłowice town is located within two mesoregions of south part of Silesian Upland: Katowice Upland (sign in Polish decimal system 341.13) and Jaworzno Hills (341.14). The town is situated in central part of Silesian Voivodeship, within the Upper Silesian conurbation (Katowice conurbation), and has special status (town-poviat, in Polish nomenclature: powiat grodzki). The area of Mysłowice is $65.57 \mathrm{sq} \mathrm{km}$ and the number of inhabitants is currently about 72.8 thousands. The aim of paper is distinguishing and basic analyzing the differentiation and distribution of structural-functional units at the area of mentioned town. The units were identified on the base of two criteria: functions and physiognomic type of spatial planning unit. The landscape typology method and assumptions of physicalgeographical regionalization method were used in identification process of units. The GIS methods and MapInfo Professional software were used as a main tool in this identification. All works were conducted on the base of topographic maps from 90 . of XX century, town plan (2004) and orthophotomaps (2009) in Poland CS92 coordinate system (EPSG: 2180). At Mysłowice town area the total of 17 structural-functional units were identified (3 point, 3 linear and 11 polygonal character).
\end{abstract}

Keywords: cultural landscapes; GIS methods; land use; Silesian Upland; structural-functional units.

\section{Introduction}

The areas under influence of intensive human activity are often characterized by a great degree of the natural environment degradation and the important landscape changes as a consequence [1-5]. Each component of the environment have been remodelling, beginning from the interference in geological structure, through changes in relief, climatic conditions, features of hydrographic network and underground waters or soil, vegetation cover and animal world, often resulting from the earlier mentioned transformations [6-8]. The changes are especially visible in diverse of relief form of waste dump (mining, metallurgical and power ash waste) [3,9], inactive quarries [10-11] and subsidence depressions [12]. An example of such areas is the Silesian Upland at south part of Poland.

The area of Mysłowice town - located in south part of Silesian Upland and central part of Silesian Voivodeship - is changed since centuries by intensive human activity [13-14]. Due to high human impact the natural landscapes of this area are almost complete destroyed or are degraded in significant degree. The aim of paper is distinguishing and basic analyzing the differentiation and distribution of structural-functional units at this town area. The units were identified in order to better understanding of contemporary cultural landscapes at area of town. The units - referring to the land use form - are synthetic approach to the landscapes forming within the administrative boundaries of Mysłowice town.

\section{Study area}

The Mysłowice town is located within two mesoregions of south part of Silesian Upland [15]: Katowice Upland (sign in Polish decimal system 341.13) and Jaworzno Hills (341.14). The town is located in central part of Silesian Voivodeship and has special status (powiat grodzki, town-poviat). The area of Mysłowice is $65.57 \mathrm{sq} \mathrm{km}$ and the number of inhabitants is currently about 72.8 thousands. Town is located within the Upper Silesian conurbation (different name: Katowice

Corresponding author: Tomasz Parusel. E-mail address: tp_oficjal@interia.pl

http://dx.doi.org/10.3846/enviro.2014.138

(C) 2014 The Authors. Published by VGTU Press. This is anopen-access article distributed under the terms of the Creative Commons Attribution License, which permits unrestricted use, distribution, and reproduction in any medium, provided the original author and source are credited. 
conurbation) [16]. Characteristic of town area is limited to the basic features of geological structure, relief, hydrographic conditions, soils and the distribution of forests, as a main environmental conditions for development of chosen structuralfunctional units.

The area of Mysłowice town is located within the Upper Silesian basin. The Precambrian crystalline rocks are in deepground and Upper Carboniferous, Triassic, tertiary and quaternary layers are in zones near the surface. The Carboniferous rocks dominate in the part of the town in Katowice Upland mesoregion (north and central part of town area on Fig. 1). The Triassic dolomites, marls and limestones are only in the south and south-east part of study area (Jaworzno Hills mesoregion) [17] and have been exploited in numerous quarries [11, 18]. Tertiary sediments - Miocene sands and clays fill the depressions of older ground. The Pleistocene sands, gravels and clays and Holocene sediments (river alluvia and sands within the lowest floodplain terrace in the river valleys) are on the surface [17].

The maximum relative height at the town area is 100.5 meters, the highest point reaches 334 meters a.s.l. and the lowest $-233.5 \mathrm{~m}$ a.s.l. However, most of town area has is flat with inclination not exceeding $3 \%$. The slopes are not very steep (up to $30 \%$ ), only in active and inactive quarries are vertical rock walls. The main character of relief is associated with Alpine orogenesis (for example Przemsza river gap in south-east part of town) [17], but contemporary relief of town area is conditioned by intensive human impact. The anthropogenic relief forms are better visible than natural elements in the most part of town area [18].

The main river network in Mysłowice is formed by the Przemsza river with tributaries and Przyrwa river (tributary of Mleczna river). This system is complemented by numerous drainage ditches and artificial water reservoirs - subsidence depressions, ponds and industrial settling ponds [12]. Contemporary state of water relations is the effect of their natural development in Holocene and - especially - was conditioned by intensive human activity [18]. The soil cover in Mysłowice, due to the varied geological structure, should be more different potentially. However, the anthropogenic Technosols and Anthroposols dominate at the built-up and commercial areas of town. Furthermore, it is possible to indicate the areas completely devoid of any soil cover and with high toxic soils, which is confirmed by researches conducted in selected parts of town [3]. The natural soils are represented only by small fragments within forests and in south and southeast part of town area. The forest complexes are characterized by multiple transformation in species composition and currently a lack of conformity with actual vegetation and original habitat is observed [18]. The differentiation of species composition of other habitats is connected with anthropogenic landforms also [19].

\section{Materials and methods}

In the identification process of structural-functional units in the Mysłowice town were used two criteria: 1. functions of spatial planning unit, 2. physiognomic type of unit. The divide of main structural-functional unit types was based on first criteria. The divide of unit subtypes was based on second criteria. The basis for units classification was their similarity within the criteria, regarding to the landscape typology method [20]. Only one object was classified as individual unit (RTV Sending Centre) - in this case the assumptions of physical-geographical regionalization method were applied [15, 20]. In the identification the authors has been suggested by insights of Šimanauskienè and Rahmonov [21] also.

The identification of structural-functional units was conducted with applying GIS methods in MapInfo Professional software. The units were classified on the base of topographic maps from 90. of XX century (in scales 1:10 000 and 1:50 000), town plan from 2004 (scale 1:20 000) and orthophotomaps from 2009 (1:5 000). All cartographic materials were calibrated and registered in Poland CS92 coordinate system (EPSG: 2180). The boundaries of identified structuralfunctional units were corrected in the field works also.

\section{Results and discussion}

The total of 17 structural-functional units were identified at the area of Mysłowice town. The units are divided to 3 point, 3 linear and 11 polygonal character (Table 1 and Fig. 1). Within two main unit the subtypes are divided: in river network -3 subtypes and in road network - 2 subtypes.

Table 1. The structural-functional units identified at the area of Mysłowice town

\begin{tabular}{ll}
\hline Unit types & Unit characteristic and notes \\
\hline public buildings & \multicolumn{1}{c}{ point units } \\
churchs & $\begin{array}{l}\text { government offices (Tax Office) and local government (Town Hall), schools, } \\
\text { hospitals, sports halls, libraries, cinemas, health centers, museums, police office } \\
\text { the religious function }\end{array}$ \\
RTV Sending Centre & RTV Sending Centre "Katowice-Kosztowy" \\
\hline river network & \multicolumn{1}{c}{ linear units } \\
railways & 3 subtypes: main rivers, greater tributaries, other greater water-courses \\
road network & Polish National Railways (PKP) and railways managed by commercial operators \\
\hline
\end{tabular}




\begin{tabular}{|c|c|}
\hline Unit types & Unit characteristic and notes \\
\hline \multicolumn{2}{|r|}{ polygonal units } \\
\hline multi-family and mixed buildings & $\begin{array}{l}\text { multi-family residential areas (blocks and tenement houses, including single } \\
\text { buildings) }\end{array}$ \\
\hline single-family buildings & only single-family housing areas \\
\hline industrial areas & contemporary and former industrial areas \\
\hline great-area service terrains & large-commercial buildings, storage and service \\
\hline sport-recreation areas & urban parks, larger public gardens and sports grounds \\
\hline forests & $\begin{array}{l}\text { large area dense forests, small patches of their complexes and shelterbelts between } \\
\text { other units }\end{array}$ \\
\hline agricultural terrains & $\begin{array}{l}\text { agricultural lands and grasslands, including fallow lands (but excluding fallow many } \\
\text { years - wasteland) }\end{array}$ \\
\hline cemeteries & the religious function \\
\hline water reservoirs & subsidence depressions, ponds and industrial settling ponds \\
\hline allotment gardens & additional function of agricultural production (not only recreational function) \\
\hline wastelands & other areas in the town \\
\hline
\end{tabular}

The contemporary settlement network in the town area has developed in the two types - multi- and single-family building (Table 1 and Fig. 1). Both types are connected (mainly in the Przemsza river valley and in south-east part of town area) with environmental conditions and shape of forest complexes. The original forest areas were destroyed [18], but in Mysłowice we can observe that the current spatial structure clearly refer to forest structure in the past, expressing by their latitudinal shape (Fig. 1). It should be emphasized that the kind of older buildings in south-east part of the town is strongly connected with geological structure [11] - the Triassic dolomites, marls and limestones (Fig. 2).

The actual distribution of buildings areas are connected to main road network in Mysłowice also. The main roads refer to the course of historical trade routes also [22], which are the basis of the current road system (Fig. 1). Only two road in the town area - motorway A4 and highway S1 - do not show any connection to environmental conditions and distribution of others structural-functional units.

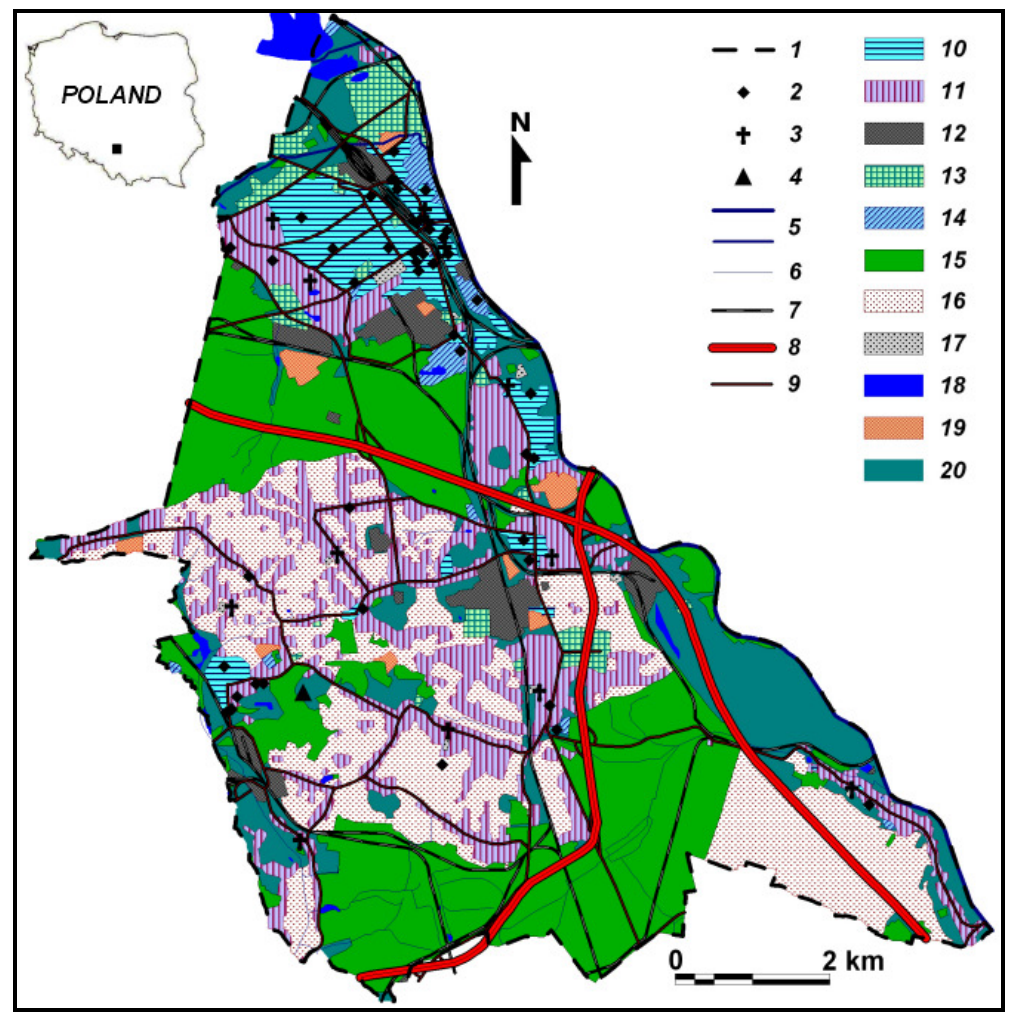

Fig. 1. The map of structural-functional units in Mysłowice town (explanations: 1 - town border; 2 - public objects; 3 - churchs; 4 - RTV Sending Centre; 5 - main rivers with greater tributaries; 6 - other greater water-courses; 7 - railways; 8 - motorways and highways; 9 - main roads; 10 - multi-family and mixed buildings; 11 - single-family buildings; 12 - industrial areas; 13 - great-area service terrains; 14 - sport-recreation areas; 15 - forests;

16 - agricultural terrains; 17 - cemeteries; 18 - water reservoirs; 19 - allotment gardens; 20 - wastelands) 
The environmental conditions of development and current shape of unit are especially visible in the case of agricultural areas. In Mysłowice this unit is located mainly in south part of town area (Fig. 1). This distribution is due to the current settlement network shape and the character of soil cover. In the south part of the town soils are degraded in lower degree than at the north part. In the south part of town area - due to occurrence of dolomites, marls and limestones in the ground [17] - were developed the Rendzinas, very fertile soils [18]. With this unit is connected the existence of open landscapes, especially valuable in urban areas [23].

The separate problem is the distribution and character of wasteland [1]. This unit dominate on the undeveloped areas in the north, the most urbanized and industrialized part of the town and in south-east part (Fig. 1) - the former ash landfills of Jaworzno III Power Plant [3, 5, 9]. In other part of town wastelands is located around of other identified units, mainly along the transportation routes and proximity of industrial and post-industrial areas $[1,4]$. The majority of wastelands have the economic character associated with the abandonment of agricultural, service or industrial activities. The contemporary important problem connected with wastelands is the invasion of alien species, especially from Fallopia sp. genus [24].

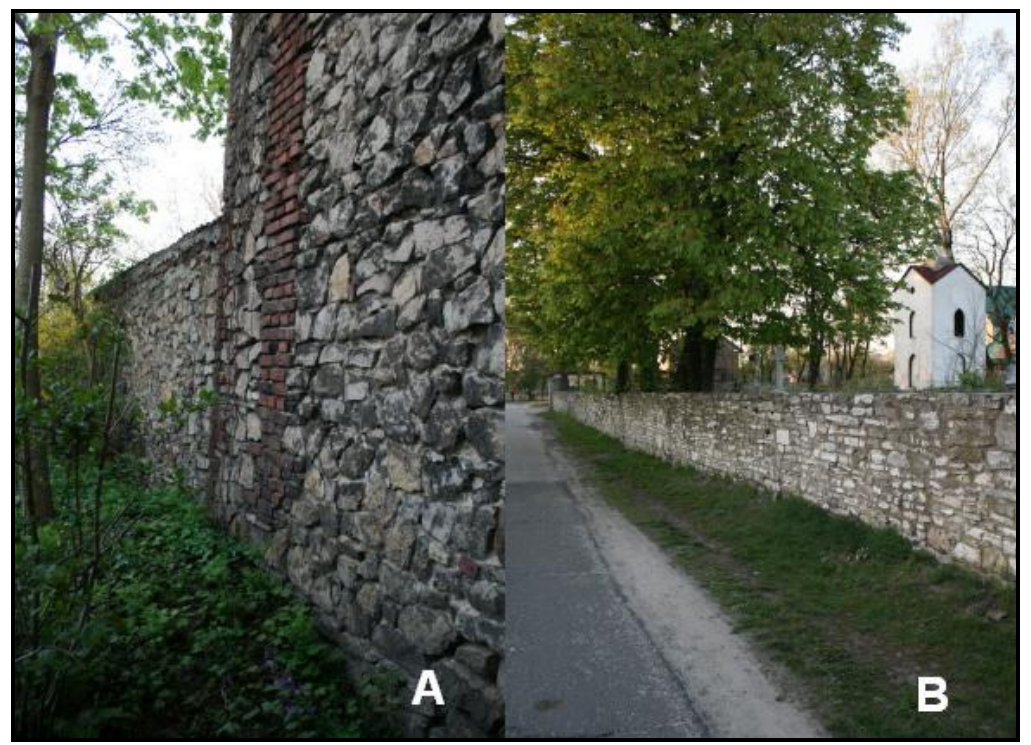

Fig. 2. The limestone buildings at south-east part of the town (A - house; $\mathrm{B}$ - stone wall at the cemetery)

\section{Conclusions}

The obtained results are the trial classification of cultural landscapes as a structural-functional units at the area of Myslowice town. The study area is changed since centuries by intensive human activity and the natural landscapes are almost complete destroyed or are degraded in significant degree. The structural-functional units were identified in order to better understanding of contemporary cultural landscapes at area of town. The applying the GIS methods and software were very important to understanding of landscape changes in the urban areas, especially in regions of very intensive human activity.

\section{References}

[1] Oleś, W.; Rahmonov, O.; Rzętała, M.; Malik, I.; Pytel, S. 2004. The ways of industrial wastelands management in the landscape of Silesian Region, Ekológia (Bratislava) 23(suppl.1): 244-251.

[2] Rahmonov, O.; Rzętała, M.; Malik, I.; Oleś, W.; Pytel, S. 2004. Possibilities of applying Salix acutifolia in revitalizing areas transformed by anthropogenic activity, Ekológia (Bratislava) 23(suppl.1): 280-290.

[3] Rahmonov, O.; Parusel, T. 2011. Vegetation succession and soil development in an area transformed by human impact - reclaimed ash landfills, in The 8th International Conference "Environmental Engineering”. Selected papers. Vilnius: Vilnius Gediminas Technical University, 323-330.

[4] Rahmonov, O.; Szymczyk, A.; Majgier, L.; Banaszek, J.; Parusel, T.; Karkosz, D. 2012. The conception of management of post-industrial landscapes in the light of sustainable development, in Proc. of the International Conference "Geographical sciences in realization of sustainable development strategy in globalizing world (to the 100th anniversary of Professor N. T. Romanovskij) ", Minsk, Belarus, 2012. Minsk: Belarusian State University, 289-291.

[5] Rahmonov, O.; Snytko, V. A.; Szczypek, T.; Parusel, T. 2013. Vegetation development on post-industrial territories of the Silesian Upland (Southern Poland), Geography and Natural Resources 34(1): 96-103.

[6] Rahmonov, O; Oleś, W. 2010. Vegetation succession over an area of a medieval ecological disaster. The case of the Błędów Desert, Poland, Erdkunde 64(3): 241-255. http://dx.doi.org/10.3112/erdkunde.2010.03.03

[7] Rahmonov, O.; Kowalski, W. J.; Bednarek, R. 2010. Characterization of the soil organic matter and plant tissues in an initial stage of plant succession and soil development by means of Curie-point pyrolysis coupled with GC-MS, Eurasian Soil Science 43(13): 1557-1568. http://dx.doi.org/10.1134/S1064229310130144

[8] Rahmonov, O.; Rzętała, M. A.; Rahmonov, M.; Kozyreva, E.; Jaguś, A.; Rzętała, M. 2011. The formation of soil chemistry and the development of fertility islands under plant canopies in sandy areas, Research Journal of Chemistry and Environment 15(2): 823-829. 
[9] Рахмонов, О.; Щипек, Т.; Парусель, Т. 2012. Формирование экосистем на антропогенно преобразованных территориях (на примере золоотвалов теплоэлекростанции) [Ecosystems development on anthropogenic changed areas (reclaimed ash landfills case study)], Geographia. Studia et Dissertationes [Geography. Studies and Dissertations] 34: 57-75.

[10] Badera, J.; Rahmonov, O.; Parusel, T. 2011. The quarry in Kozy as a geotourist attraction and the object of natural and cultural heritage in the context of sustainable development, Geotourism 3-4(26-27): 41-50.

[11] Parusel, T.; Karkosz, D.; Meisel, A. 2010. Garb Dziećkowic i Przełom Przemszy (Wyżyna Śląska) jako potencjalne obszary turystyki ekologicznej uwarunkowania przyrodnicze [The Dziećkowice Ridge and Przemsza Gap (Silesian Upland) as a potential areas of ecological tourism - natural conditions], Problemy Ekologii Krajobrazu [The Problems of Landscape Ecology] 27: 313-319.

[12] Pełka-Gościniak, J.; Rahmonov, O.; Szczypek, T. 2008. Water reservoirs in subsidence depressions in landscape of the Silesian Upland (Southern Poland), in The 7th International Conference "Environmental Engineering". Selected papers. Vilnius: Vilnius Gediminas Technical University, 257261.

[13] Sulik, A. 2007. Historia Mysłowic do 1922 roku. Mysłowice: Press of Mysłowice Town Hall. 376 p. ISBN 83-921951-3-2.

[14] Sulik, A. 2011. Tom II. Historia Mystowic 1922-1945. Miasto w Polsce Odrodzonej 1922-1939 i Trzeciej Rzeszy Niemieckiej 1939-1945. Mysłowice: HEJME Press. 502 p. ISBN 978-83-931306-3-4.

[15] Kondracki, J. 2011. Geografia regionalna Polski. Warszawa: Polish Scientific Press. 468 p. ISBN 978-83-01-16022-7.

[16] Dragan, W. 2012. Problem demograficznego kurczenia się miast na przykładzie Mysłowic [The problem of demographic shrinkage of towns on example of Mysłowice], in S. Sitek. "Stare i nowe" problemy badawcze w geografii spoleczno-ekonomicznej. Zeszyt 4 ["Old and new" problems in socio-economic geography. Issue 4]. Sosnowiec: Polish Geographical Union, Katowice Branch, University of Silesia, Faculty of Earth Sciences, 3345. ISBN 978-83-61695-14-1.

[17] Racki, G.; Bardziński, W.; Zieliński, T. 1999. Z kamiennej księgi pradziejów Górnego Śląsk. Przewodnik geologiczny. Katowice: University of Silesia Press. 169 p. ISBN 83-226-0873-X

[18] Czylok, A.; Gądek, B.; Tyc, A. 2002. Przyroda Mysłowic. Przewodnik przyrodniczy po mieście Mystowice. Mysłowice: Press of Mysłowice Town Hall. 144 p. ISBN 83-913070-3-4.

[19] Rahmonov, O.; Snytko, V. A.; Szczypek, T. 2009. Phytogenic hillocks as an effect of indirect human activity, Zeitschrift für Geomorphologie N.F. 53(3): 359-370.

[20] Ostaszewska, K. 2002. Geografia krajobrazu. Wybrane zagadnienia metodologiczne. Warszawa: Polish Scientific Press. 278 p. ISBN 83-01-13648-0.

[21] Šimanauskienè, R.; Rahmonov, O. 2005. The problem of geobiocomplex distinguishing methodology, in The 6th International Conference "Environmental Engineering”. Selected papers. Vilnius: Vilnius Gediminas Technical University, 999-1004.

[22] Złoty, A. 2002. Zaczarowany świat kartografii. Część I. Dynastia Plessensis. Pszczyna: The Economic Brotherhood of the Upper Silesian Association. 72 p. ISBN 83-913619-5-0.

[23] Myga-Piątek, U. 2012. Krajobrazy kulturowe. Aspekty ewolucyjne i typologiczne. Katowice: University of Silesia Press. 404 p. ISBN 978-83-6265239-6.

[24] Rahmonov, O.; Czylok, A.; Orczewska, A.; Majgier, L.; Parusel, T. 2014. Chemical composition of the leaves of Reynoutria japonica Houtt. and soil features in polluted areas, Central European Journal of Biology 9(3): 320-330. http://dx.doi.org/10.2478/s11535-013-0267-9 